\title{
Sensitive and specific polymerase chain reaction assay for detection of Loma salmonae (Microsporea)
}

\author{
Margaret F. Docker ${ }^{1}$, Robert H. Devlin ${ }^{1}$, Jon Richard ${ }^{2}$, Jaswinder Khattra ${ }^{1}$, \\ Michael L. Kent ${ }^{2, *}$ \\ ${ }^{1}$ West Vancouver Laboratory, Department of Fisheries and Oceans, 4160 Marine Drive, West Vancouver, \\ British Columbia, Canada V7V 1N6 \\ ${ }^{2}$ Pacific Biological Station, Department of Fisheries and Oceans, Nanaimo, British Columbia, Canada V9R 5K6
}

\begin{abstract}
Ribosomal DNA sequence of the microsporidian parasite Loma salmonae, including portions of the small subunit (SSU), large subunit (LSU), and internal transcribed spacer regions (ITS), was determined. Based on L. salmonae-specific regions of sequence, a polymerase chain reaction (PCR) assay was developed for detection of this parasite in chinook salmon Oncorhynchus tshawytscha. The specificity of the assay was verified by the lack of amplification with DNA from 3 other microsporidians that parasitize fishes in British Columbia, Canada. A dilution study assessed the sensitivity of the test, showing that the PCR product (derived from multiple copies of rDNA per cell) was routinely detected from as few as 0.01 spores per $50 \mu$ reaction (or 40 spores $\mathrm{g}^{-1}$ of infected gill tissue). The assay detected L. salmonae infections in the gills, kidneys, and ovaries of broodstock females from a seawater netpen on Vancouver Island, British Columbia, and infections in these organs were confirmed by histology. This is the first report of $L$. salmonae infections in ovarian tissue. Although neither PCR nor histology detected L. salmonae within the eggs themselves, it is possible that the progeny of infected females may become exposed to the parasite through contaminated ovarian fluid.
\end{abstract}

KEY WORDS: Loma Salmonae - Microsporidia - Ribosomal DNA - Polymerase chain reaction

\section{INTRODUCTION}

Loma salmonae (Microsporea) is an obligate, intracellular parasite which infects the gills and other vascularized tissues of salmonids of the genus Oncorhynchus from fresh water throughout the Pacific Northwest of North America (Wales \& Wolf 1955, Putz et al. 1965, Morrison \& Sprague 1981c, 1983, Hauck 1984, Magor 1987). Similar, if not identical, species have also been reported in several Oncorhynchus species from the eastern United States (Markey et al. 1994), Great Britain (Poynton 1986), France (Bekhti \& Bouix 1985), and Japan (Awakura et al. 1982). The infection can persist after fish are transferred to sea water (Wood 1974). In fact, the pathological changes associated with $L$. salmonae infection may be more

·Addressee for correspondence. E-mail: kentm@pbs.dfo.ca severe in salmonids in sea water (Kent et al. 1989), and the parasite can easily be transmitted from fish to fish while in sea water (Kent et al. 1995). Consequently, $L$. salmonae has been a serious problem in pen-reared chinook Oncorhynchus tshawytscha and coho salmon O. kisutch in the Pacific Northwest (Kent et al. 1989, Speare et al. 1989, Kent 1992).

Although preliminary experiments suggest that an antimicrobial agent, Fumagillin $\mathrm{DCH}$, may be a useful therapeutant for controlling Loma salmonae (Kent \& Dawe 1994), no drugs are commercially available for treatment against this parasite. At present, this disease is best controlled by avoiding the spread of infection. The main problem facing this strategy, however, is determining the source of infection. Although the disease can originate in fresh water, a high prevalence of $L$. salmonae infection was observed in chinook from 1 netpen that had been reared solely on ground water during the freshwater phase (Kent et al. 1995). Vertical 
transmission, from infected females directly into the eggs, or seawater horizontal transmission from a nonsalmonid fish may also be sources of infection. The spores of other fish microsporidians have been found in the mature ova of the host (Vaney \& Conte 1901, Summerfelt \& Warner 1970) and, although L. salmonae has only been reported from salmonids, very similar Loma species have been reported from strictly marine fishes (Morrison \& Sprague 1981a, b).

Studies on the mode of transmission of Loma salmonae, and the application of routine screening to limit its spread in netpens, have been limited by the ability of histological analysis to detect infection. Fish may be infected for several weeks, if not months, before the parasite can be observed in histological sections, and this method often lacks sensitivity. The purpose of this study, therefore, was to develop a sensitive and specific DNA-based assay for the detection of $L$. salmonae in chinook salmon. $L$. salmonae ribosomal DNA (rDNA), comprising portions of the small subunit (SSU) and large subunit (LSU) genes and the internal transcribed spacer (ITS) region, was sequenced. Using species-specific regions of this sequence, we developed a polymerase chain reaction (PCR) test that can detect very small amounts of $L$. salmonae DNA, even when mixed with a very large amount of host DNA.

\section{MATERIALS AND METHODS}

Loma salmonae ribosomal DNA sequence. Specimen collection: For the initial isolation of Loma salmonae for DNA extraction and sequencing, chinook salmon were collected in March 1995 from a seawater netpen on the west coast of Vancouver Island with a history of the infection. Gills showing infection by $L$ salmonae were frozen at $-70^{\circ} \mathrm{C}$. Control (uninfected) chinook salmon were from the Rosewall Creek Hatchery, Fisheries and Oceans Canada, Vancouver Island, Canada, which receives only pure well water and has no history of the disease. Subsamples of tissues were also preserved in Davidson's solution for histological verification of infection. These latter samples were processed for light microscopy using standard histological techniques (Humason 1979), and the sections were stained with Harris' hematoxylin and eosin.

Spore isolation: Tissue from heavily infected gills were scraped into Earl's Buffered Saline Solution (EBSS), and centrifuged at $1200 \times \mathrm{g}$ for $10 \mathrm{~min}$. The pellet was resuspended in EBSS, homogenized at low speed, and centrifugation and resuspension were repeated. Large pieces of tissue debris were removed by successive filtration through a wire mesh and then a $50 \mu \mathrm{m}$ nylon screen. The filtrate was layered onto a
$34 / 51 \%$ Percoll gradient and centrifuged at $500 \times g$ for 45 to $60 \mathrm{~min}$. The layers and pellet were removed separately, concentrated by a further 10 min centrifugation at $1200 \times g$, and the spores were stored at $-70^{\circ} \mathrm{C}$. Throughout the process, visual inspection verified the presence of the intact spores at each step

DNA isolation and PCR: Host and parasite DNA were extracted from ca $30 \mathrm{mg}$ Loma salmonae-infected gills by shaking with $0.5 \mathrm{~mm}$ silica beads in TE buffer (10 mM tris, 1 mM EDTA), pH 8.0, for 3 min in a MiniBeadbeater (Biospec Products, Bartlesville, OK, USA). The suspension was extracted twice with phenol chloroform, and the DNA precipitated on ice with sodium acetate and ethanol. The DNA was resuspended in TE, quantitated, and stored at $4^{\circ} \mathrm{C}$. DNA was similarly extracted from ca $40 \mu$ lpacked volume) of purified $L$. salmonae spores, although $1 \mu \mathrm{gl}^{-1}$ yeast tRNA was added to the TE prior to bead-beating to enhance DNA recovery.

Loma salmonae rDNA was amplified using PCR, with primers described by Vossbrinck et al. (1987). The forward primer 530 f (5'-GTGCCAGC(C/A)GCCGCGG-3') and reverse primer 580r (5'-GGTCCGTGTTTCAAGACGG-3') are located in the SSU and LSU rDNA genes, respectively (Fig. 1), and have been used successfully in several other microsporidia to amplify rDNA fragments of ca 1350 to 1550 bp in length (Vossbrinck et al. 1993, Zhu et al. 1994).

Each $50 \mu \mathrm{l}$ reaction used standard PCR buffer (Gibco BRL, Gaithersburg, MD, USA), $1.5 \mathrm{mM} \mathrm{MgCl}$, and $0.2 \mathrm{mM}$ dNTP, $25 \mathrm{pmol}$ of each primer, 1.25 units of Taq DNA polymerase (Bethesda Research Laboratory, MD, USA), and $0.6 \mu \mathrm{g}$ of template DNA. The reactions were run in a Perkin Elmer GeneAmp 9600 Thermocycler (Perkin Elmer Cetus, Norwalk, CT, USA) for 30 cycles consisting of denaturation at $94^{\circ} \mathrm{C}$ for $1 \mathrm{~min}$, primer annealing at $50^{\circ} \mathrm{C}$ for $1 \mathrm{~min}$, and extension at $72^{\circ} \mathrm{C}$ for $3 \mathrm{~min}$, which were preceded by an initial 3 min denaturation at $95^{\circ} \mathrm{C}$ and followed by a final $10 \mathrm{~min} 72^{\circ} \mathrm{C}$ extension. Negative controls, which used distilled water instead of template DNA, were included

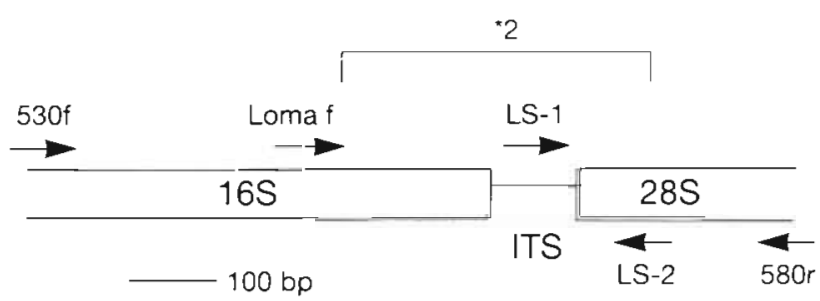

Fig. 1. Structural organization of the Loma salmonae rDNA fragment amplified with primers $530 \mathrm{f}$ and $580 \mathrm{r}$; an additional 400 to $500 \mathrm{bp}$ of the small subunit gene and 2500 to $3500 \mathrm{bp}$ of large subunit are located at the $5^{\prime}$ - and $3^{\prime}$-ends, respectively. Locations of primers Loma f, LS-1, and LS-2 are given, and the region sequenced in a second isolate of $L$. salmonae is indicated by the square bracket $\left({ }^{\circ} 2\right)$ 
Fig. 2. Partial sequence alignment of Loma salmonae from chinook salmon and Microsporidium $\mathrm{sp}$. from whitefish. demonstrating sequence variability in the regions of the L. salmonae-specific primers, LS-1 and LS-2. Dashes indicate gaps inserted in the sequence alignment, and asterisks show identical bases between the 2 species. Presumptive internal transcribed spacer region is shown in lower case letters, and numbers on the right indicate the number of nucleotides from the $3^{\prime}$-end of the 530 primer

\author{
Loma salmonae \\ Microsporidium sp. \\ Loma salmonae \\ Microsporidium sp. \\ Loma salmonae \\ Microsporialum sp. \\ Loma salmonae \\ Microsporidium sp. -
}
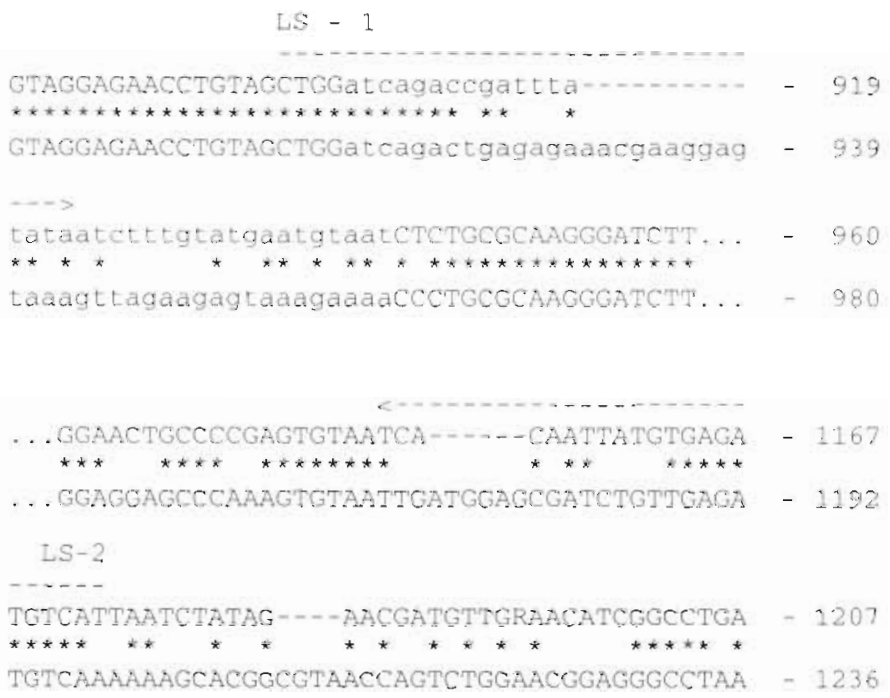

in each series of reactions to screen for possible contamination. The Loma salmonae-specific PCR product was excised from low melting point agarose and purified, according to the freeze-thaw method of Qian \& Wilkinson (1991), for subsequent cloning and/or sequencing.

Cloning and sequencing: Primers 530f and 580r were synthesized to include EcoRI and BamHI restriction sites, respectively, at their 5'-ends. The PCR product from isolated Loma salmonae spores was cut with these restriction enzymes and cloned into the phagemid vector pBluescript II (SK-and SK+) (Stratagene Corp., La Jolla, CA, USA) by standard procedure (Sambrook et al. 1989). DNA was purified from overnight cultures by standard alkaline lysis miniprep protocol (Sambrook et al. 1989).

One clone within each of the SK- and SK+ vectors was selected, and the presence of the desired inserts were verified by restriction enzyme digests. Singlestranded DNA was generated from both clones using VCS-M13 helper phage (Stratagene). Both strands of the 2 clones were sequenced from single- and doublestranded DNA using the Sequenase Version 2.0 DNA Sequencing Kit (United States Biochemical, Cleveland, $\mathrm{OH}$, USA).

To examine variation in rDNA sequence between Loma salmonae isolates, the L. salmonae-specific PCR product obtained from the infected gills was reamplified

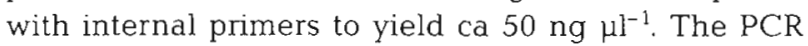
fragments were sequenced directly with the Sequenase PCR Product Sequencing Kit (USB) to generate $638 \mathrm{bp}$ of sequence spanning the ITS region (Fig. 1).

Development of the PCR test. Specimen collection: For the development and initial testing of the Loma salmonae assay, chinook salmon tissues were collected from the above-mentioned seawater netpen farm as follows. In March 1995, gills and kidneys from 14 moribund fish (avg. wt. ca $2 \mathrm{~kg}$ ) were frozen at $-70^{\circ} \mathrm{C}$. In addition, 3 control fish from Rosewall Creek were transported to the farm on ice and were sampled in between sampling of the suspect fish to evaluate the possibility of cross-contamination during the sampling process. In addition, 5 more control fish from the Rosewall Creek Hatchery were assayed at our laboratory. Tissue samples were also placed in Davidson's solution for histological analysis, as described previously.

Oligonucleotide design and PCR conditions: Presumptive Loma salmonae-specific PCR primers were designed by comparing the rDNA sequence generated above, particularly the hypervariable ITS region and variable portions of the $28 \mathrm{~S}$ gene, with those available for other microsporidians found infecting fishes in British Columbia. The rDNA sequence of the only other microsporidian known to infect chinook salmon, Nucleospora salmonis (cf. Docker et al. 1997), showed less than $60 \%$ sequence homology with that of $L$. salmonae and the ITS regions showed no resemblance. Ribosomal DNA sequence from an undescribed Microsporidium $\mathrm{sp}$. that we recently found in mountain whitefish Prosopium willamsoni muscle was ca $75 \%$ homologous with that of $L$. salmonae. L. salmonaespecific primers were designed from the regions that differed most between these species (Fig. 2). These primers, LS-1 and LS-2, amplify a 272 bp fragment.

The other PCR components were as described above, but the thermal profile was as follows: 35 cycles of $94^{\circ} \mathrm{C}$ for $1 \mathrm{~min}, 53^{\circ} \mathrm{C}$ for $1 \mathrm{~min}$, and $72^{\circ} \mathrm{C}$ for $1 \mathrm{~min}$, preceded and followed by a $3 \mathrm{~min}$ denaturation and $10 \mathrm{~min}$ extension, respectively. All DNA extractions and PCR preparations were made with aerosolresistant pipette tips, as contamination was found to be high otherwise. 
Sensitivity and specificity of the PCR: To test the specificity of the LS-1 and LS-2 primers, they were used on DNA from Nucleospora salmonis from chinook, Microsporidium sp. from whitefish, and a closely related species, Loma embiotocia, which was recently reported in shiner perch Cymatogaster aggregata (cf. Shaw et al. 1997). To determine the level of sensitivity of the PCR test, DNA from gill tissue containing a known concentration of $L$. salmonae was extracted and serially diluted with DNA from a control fish until the desired PCR fragment was no longer detected; total DNA per $50 \mu$ reaction was constant at $0.6 \mu \mathrm{g}$.

Test refinements: In an effort to streamline the PCR test and increase its sensitivity and reliability, the following aspects of the assay were examined. (1) The bead-beating method of DNA extraction was compared to proteinase $\mathrm{K}$ digestion and mechanical homogenization. In the former method, the tissues were digested in $1.5 \mathrm{ml}$ eppendorf tubes at $37^{\circ} \mathrm{C}$ for $6 \mathrm{~h}$ to overnight (10 mM Tris, pH 8.0; $10 \mathrm{mM}$ EDTA; $1 \%$ SDS: $150 \mathrm{mM} \mathrm{NaCl} ; 200 \mu \mathrm{g} \mathrm{ml}^{-1}$ proteinase $\mathrm{K}$ ) before phenol chloroform extraction and precipitation. In the latter, the tissue was homogenized in TE with mortar and pestle prior to extraction and precipitation. (2) The quantity of tissue sampled $(30,100,200$, or $300 \mathrm{mg})$ and the volume of the $\operatorname{PCR}(25,50$, or $100 \mu \mathrm{l})$ were evaluated with regards to efficiency and repeatability. (3) DNA extraction and PCR from tissues preserved in ethanol or previously embedded in paraffin (following recovery through a series of xylene and alcohol) were compared to results from frozen tissues.

Broodstock screening. Specimen collection: Given the observation of Loma salmonae DNA in the ovary of a chinook salmon (see 'Results'), the L. salmonae PCR assay was used to screen various tissues from females used for broodstock at the above-mentioned fish farm. Tissues were collected as follows: In July and August 1995, gills, kidneys, and ovaries from 26 spawned females were frozen, and the DNA from two $100 \mathrm{mg}$ subsamples was extracted from each by proteinase $\mathrm{K}$ digestion. In the ovarian samples, DNA was extracted from connective tissue and/or eggs, depending on availability, and where possible, tissues were also preserved for histological analysis (see Table 2). These females hatched and reared in fresh water at a hatchery in mainland British Columbia and then in seawater netpens on Vancouver Island. The ovarian tissue of an additional 48 females from another population at this fish farm were examined with the PCR test only. In addition to PCR with primers LS-1 and LS-2, a general Loma sp. primer (Loma f, 5'ATTAGTGAGACCTCAGCC-3') was also paired with LS-2, in case geographic differences in ITS sequence prevented LS-1 from annealing; Loma f and LS-2 amplify a 627 bp fragment in $L$. salmonae. During the extraction procedure, Atlantic salmon liver was also processed to screen for possible contamination prior to PCR. Many samples from the broodstock study were negative for $L$. salmonae by PCR analysis. Therefore, to determine whether amplifiable template was present, 47 of these samples were tested with control primers developed from conserved salmonid growth hormone $(\mathrm{GH})$ gene sequences (Devlin unpubl.).

PCR conditions: PCR components and conditions were as described above in the development of the PCR test, and reactions were performed in duplicate.

\section{RESULTS}

\section{Loma salmonae ribosomal DNA sequence}

The PCR primers 530 and 580r produced a single 1450 bp fragment with DNA from purified Loma salmonae spores. This PCR product was also evident with DNA from infected gill tissue, although several smaller bands were also present. These other bands, which were also present in the uninfected chinook samples, have been shown to be derived from salmon DNA (Docker et al. 1997).

Upon sequencing, the amplified fragment was found to consist of 1391 bp of Loma salmonae rDNA: ca $905 \mathrm{bp}$ of SSU rDNA, $37 \mathrm{bp}$ of ITS, and $449 \mathrm{bp}$ of the LSU gene, although the exact boundaries of the ITS are not known. Two nucleotide differences were noted between the 2 cloned sequences (at positions 574 and 1329), and only 1 difference was found in the $638 \mathrm{bp}$ region sequenced in both isolates (position 1194); all differences were transitions. The sequence has been deposited in GenBank (accession no. U78736).

\section{Development of the PCR test}

Oligonucleatide primers were designed from speciesspecific regions of the Loma salmonae rDNA sequence (Fig. 2), avoiding the sites of polymorphism mentioned above. Loma salmonae rDNA was detected in gill and/or kidney tissue in several fish from the seawater netpen farm (Table 1). Two of these fish exhibited no histological signs of $L$. salmonae infections, while others had xenomas or chronic, multifocal branchitis identical to that previously associated with $L$. salmonae infections (Kent et al. 1989, 1995, Speare et al. 1989). In some fish with bacterial kidney disease or plasmacytoid leukemia, L. salmonae infections were identified by PCR but not by histology (Table 1). Duplicate PCR samples concurred and there was no amplification in the negative controls, including those collected at the farm site, suggesting that the positive resuits were not due to contamination. 
Table 1. Loma salmonae in seawater pen-reared chinook salmon. PCR results compared to histological analysis. -: negative; + : positive; ++ : strong positive; CMB: chronic, multifocal branchitis; RC: Rosewall Creek control stock; BKD: bacterial kidney disease; PL: plasmacytoid leukemia with Nucleospora salmonis infection (unless otherwise indicated)

\begin{tabular}{|c|c|c|c|}
\hline \multirow{2}{*}{ Fish no. } & \multicolumn{2}{|c|}{ PCR } & \multirow{2}{*}{ Histology } \\
\hline & Kidney & Gill & \\
\hline $1-5$ & - & - & Normal-Controls from RC \\
\hline 6 & - & - & $\mathrm{BKD}$ \\
\hline 7 & - & & Normal-RC control sampled at farm \\
\hline 8 & + & - & PL \\
\hline 9 & - & & Normal-RC control sampled at farm \\
\hline 10 & + & & L. salmonae xenomas in gills \\
\hline 11 & - & + & BKD with $\mathrm{CMB}$ \\
\hline 12 & - & - & Normal-RC control sampled at farm \\
\hline 13 & - & & Normal \\
\hline 14 & - & & BKD and PL with no $N$. salmonis \\
\hline 15 & - & - & BKD with $\mathrm{CMB}$ \\
\hline 16 & - & - & $\mathrm{CMB}$ \\
\hline 17 & ++ & ++ & L. salmonae xenomas in gills \\
\hline 18 & - & ++ & $\begin{array}{l}\text { PL with CMB. One L. salmonae spore } \\
\text { observed in } 1 \text { granuloma }\end{array}$ \\
\hline 19 & - & + & $\begin{array}{l}\text { BKD, with } 1 \text { small focus } \\
\text { of inflammation in gill }\end{array}$ \\
\hline
\end{tabular}

but larger quantities required the use of tubes which would no longer fit in the benchtop centrifuge and limited the numbers of tests that could be performed. Of 25, 50, and $100 \mu \mathrm{l}$, PCR volumes of $50 \mu \mathrm{l}$ were preferred: all were found to be equivalent at high levels of infection, but light infections could only sporadically be detected at $25 \mu \mathrm{l}$ and any slight increase in the sensitivity of the assay at $100 \mu \mathrm{l}$ was not considered to be worth the added expense. (3) DNA could easily be amplified by PCR from tissues which had been frozen or preserved in ethanol, but not from formalin-fixed paraffinembedded tissues, using these extraction methods.

\section{Broodstock screening}

Of 26 females examined, 2 fish were found to have light or sporadic infections in the gills based on PCR results.
Of 4 microsporidians assayed in the specificity test, the LS-1 and LS-2 primers amplified DNA only from Loma salmonae (Fig. 3). In the sensitivity test, DNA originating from as few as 0.01 spores could routinely be detected in a $50 \mu \mathrm{l} \mathrm{PCR} \mathrm{(Fig.} \mathrm{3)} \mathrm{and} \mathrm{a} \mathrm{faint} \mathrm{PCR} \mathrm{product} \mathrm{was} \mathrm{some-}$ times visible at 0.001 spores per reaction. Consequently, under the conditions described, the PCR assay is capable of detecting between 4 and 40 spores $\mathrm{g}^{-1}$ of gill tissue. PCR with the more general primer pair, Loma $f$ and LS-2, was capable of detecting between 1 and 10 spores per reaction.

Evaluation of the various aspects of the assay led to the following observations: (1) Of the 3 methods of DNA extraction compared, all were equivalent in terms of the recovery of amplifiable Loma salmonae DNA. In terms of ease of handling, however, the proteinase $\mathrm{K}$ method was least labour-intensive. Mechanical homogenization was moderate in complexity, requiring multiple homogenizers or extremely thorough cleaning between each sample. The bead-beating method involved the most handling and was more prone to cross-contamination than the others. A $6 \mathrm{~h}$ proteinase $\mathrm{K}$ digestion was found to be sufficient, as was a single phenol chloroform extraction. (2) DNA from 30 and $100 \mathrm{mg}$ of tissue could easily be extracted in $1.5 \mathrm{ml}$ eppendorf tubes,
In these fish, Loma salmonae spores were not detected by histology, i.e. either the gills were normal or they exhibited multifocal, chronic branchitis with no evidence of spores within the lesions (Table 2). The kidney of 1 fish was positive by the PCR test, and was negative by histology. In only 1 fish did the PCR fail to detect an infection which had been observed by histology. L. salmonae rDNA was found in the ovaries of 4 females by PCR, and the presence of xenomas in
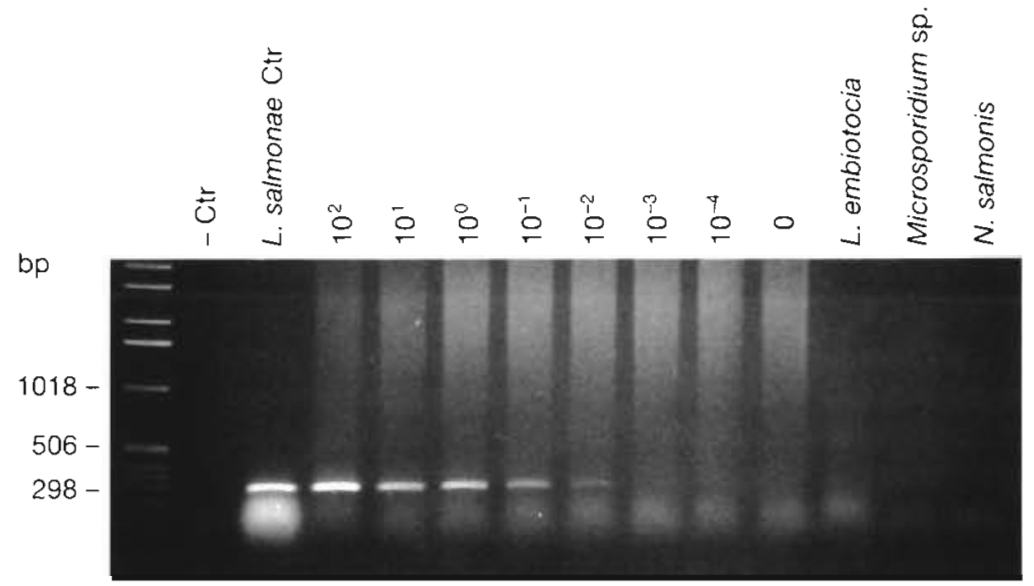

Fig. 3. Sensitivity and specificity of the Loma salmonae primers LS-1 and LS2 ( $1 \%$ agarose gel, ethidium-bromide stained). The negative and positive controls (Ctr), respectively, used distilled water and DNA from purified $L$. salmonae spores. DNA for the dilution study was extracted from gill tissue containing a known number of spores per gram. Molecular weight markers (base pairs) are shown in the left lane 
Table 2. Detection of Loma salmonae in various tissues of mature female chinook salmon. Where available, results obtained by PCR and histology are compared. Ovary refers to ovarian connective tissue; - : negative; + : positive ++ : strong positive; blank space indicates tissue not tested, $\mathrm{CMB}$ : chronic multifocal branchitis

\begin{tabular}{|c|c|c|c|c|c|c|c|c|}
\hline $\begin{array}{l}\text { Fish } \\
\text { no. }\end{array}$ & PCR & $\begin{array}{l}\text { Gill } \\
\text { Histology }\end{array}$ & ${ }_{\mathrm{PCR}}^{\mathrm{K}}$ & $\begin{array}{l}\text { idney } \\
\text { Histology }\end{array}$ & PCR & $\begin{array}{l}\text { Ovary } \\
\text { Histology }\end{array}$ & PCR & $\begin{array}{l}\text { Egg } \\
\text { R Histology }\end{array}$ \\
\hline 1 & - & - & - & - & - & - & & - \\
\hline 2 & - & - & - & - & & - & - & - \\
\hline 3 & - & _- & - & - & & - & - & - \\
\hline 4 & - & - & - & - & & - & - & - \\
\hline 5 & - & - & - & - & & - & - & - \\
\hline 6 & _- & _- & - & - & & - & - & - \\
\hline 7 & - & - & - & - & & - & - & - \\
\hline 8 & - & _- & - & - & & - & - & - \\
\hline 9 & - & - & - & - & - & - & - & - \\
\hline 10 & -- & - & - & - & - & - & - & - \\
\hline 11 & - & & - & - & & & - & \\
\hline 12 & _- & & - & - & & & - & \\
\hline 13 & - & & - & - & & & - & \\
\hline 14 & - & & - & - & & & - & \\
\hline 15 & - & & - & - & & & - & \\
\hline 16 & - & & - & - & & & - & \\
\hline 17 & - & & - & - & & & - & \\
\hline 18 & - & & - & - & & & - & \\
\hline 19 & - & & - & - & & & - & \\
\hline 20 & - & $\mathrm{CMB}$ & - & - & & - & - & - \\
\hline 21 & - & $\mathrm{CMB}$ & - & - & & - & - & - \\
\hline 22 & $+{ }^{\circ}$ & - & $+d$ & - & & - & - & - \\
\hline 23 & - & - & - & - & + & - & & - \\
\hline 24 & - & - & - & - & ++ & - & - & - \\
\hline 25 & $+^{d}$ & $\mathrm{CMB}$ & - & - & ++ & ++ & & - \\
\hline 26 & - & ++ & - & - & ++ & ++ & & - \\
\hline
\end{tabular}

chinook salmon DNA. The specificity and sensitivity of this test make it a valuable tool for the study of $L$. salmonae transmission (e.g. identification of sources of infection), detecting early or very mild infections, and for routine broodstock screening

The Loma salmonae-specific primers LS-1 and LS-2 failed to amplify DNA from the other microsporidia tested. The specificity of these primers allows for the differentiation of closely related, and possibily morphologically indistinguishable, species. For example, using these primers and a more conserved primer set, Shaw et al. (1997) substantiated that a Loma species from shiner perch Cymatogaster aggregata was a different species than $L$. salmonae, and it was thus given the name L. embiotocia. This was an important observation because shiner perch are common around seawater netpens in British Columbia and were considered a potential reservoir host for $L$. salmonae. The LS-1 and LS-2 primers will also amplify $L$. salmonae from other geographic regions. For example, these primers are capable of amplifying rDNA of $L$. salmonae isolates from California and ovarian blood vessels was verified by histology in 2 of these fish (Fig. 4). L. salmonae was not detected in the eggs themselves, either by PCR or by histology, including 3 other females in which the ovarian tissue tested positive for the parasite (Table 2). Because of the occurrence of $L$. salmonae in the ovaries, this organ was examined by PCR from an additional 48 broodstock females. L. salmonae was detected in the ovaries from 22 of these fish by this method. To confirm that the ca 270 bp fragment amplified from field samples was $L$. salmonae rDNA, we sequenced the PCR product from 10 of these positive ovary samples. The sequence from all samples concurred with $L$. salmonae rDNA. Of the 47 negative samples tested with conserved GH primers, 46 were found to contain amplifiable template, demonstrating that these samples were not negative due to DNA extraction problems.

\section{DISCUSSION}

The PCR test described in this study was capable of detecting very small amounts of Loma salmonae DNA, even when mixed with a very large amount of host

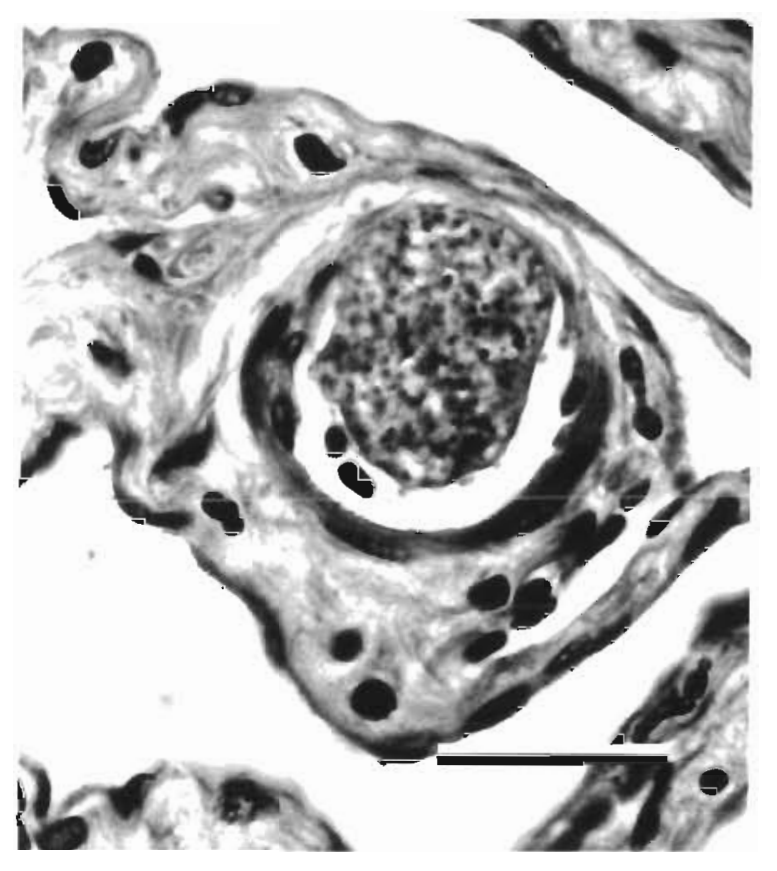

Fig. 4. Oncorhynchus tshawytscha. Blood vessel in the ovary with Loma salmonae xenoma. Hematoxylin \& Eosin. Scale bar $=25 \mu \mathrm{m}$ 
Idaho, USA (A. Brown, Department of Zoology, University of British Columbia, Vancouver, B.C., pers. comm.).

The Loma-positive PCR reaction in fish with plasmacytoid leukemia and Nucleospora salmonis infections (Table 1) was most likely due to a light infection by $L$. salmonae because the test was specifically shown not to react with the former microsporidium. Nevertheless. in situations where other closely related microsporidia are suspected, the LS-1 and LS-2 primers should be tested with other microsporidian species to broaden the conclusion that they are species specific. Barlough et al. (1995) reported a nested PCR assay for Enterocytozoon (Nucleospora) salmonis which also tested positive for a microsporidium that infects insects, Nosema necatrix. Such cross-reactivity, however, is of less concern than that from organisms which may also exist in salmon.

In addition to its specificity, the PCR assay for Loma salmonae offers a high degree of sensitivity. Both the logarithmic amplification of the PCR and the gene dosage per cell of ribosomal DNA confer a high degree of sensitivity on the assay. Although we do not know how many copies of rDNA are present in each $L$. salmonae spore, our ability to detect between 0.01 and 0.001 spores per reaction suggests at least several hundred. It appears, however, that the factor that may limit the assay's sensitivity is the amount of tissue from which the DNA is extracted. Because the PCR was capable of detecting as few as 4 to 40 spores $\mathrm{g}^{-1}$ of gill tissue, light infections may be missed in sampling only $100 \mathrm{mg}$ of tissue, especially if the spore distribution is patchy. This is the case with $L$. salmonae, in which spores are concentrated within discrete xenomas. DNA extraction from larger amounts of tissue was not practicable in $1.5 \mathrm{ml}$ eppendorf tubes, but replicate $100 \mathrm{mg}$ samples can be used where it is important to detect very light or localized infections. The small fragment size amplified by primers LS-1 and LS-2 $(272 \mathrm{bp}$ ) also improved the sensitivity of the assay by increasing the amplification efficiency; PCR using primers that amplify a $627 \mathrm{bp}$ fragment of $L$. salmonae rDNA were 3 orders of magnitude less sensitive.

Multifocal, chronic branchitis is a common lesion found in salmon in which xenomas have ruptured (Kent et al. 1989). However, spores are often difficult to detect in these lesions, and this lesion may be observed with other diseases, such as bacterial kidney disease. Our PCR test, therefore, can be useful for elucidating the cause of these lesions. For example in 1 fish in our study, only 1 spore was observed by histology, while the PCR test gave a strong reaction (Table 1).

The demonstration of Loma salmonae in ovarian tissue was largely the result of the PCR assay's sensitivity. Detection of $L$. salmonae rDNA in the ovary of 1 fish during the test's development prompted the ovarian tissue of subsequent broodstock females to be histologically examined with great care, whereupon xenomas were clearly observed in the blood vessels.

Loma salmonae infections have been observed in other vascularized tissues such as the heart, spleen, kidney, and pseudobranch (Kent et al. 1989, Markey et al. 1994), but have not previously been reported in the ovary. Although the presence of the parasite in the ovary alone does not imply true vertical transmission, it is of concern for fish farmers using $L$. salmonaeinfected broodstock. L. salmonae was not detected in the eggs themselves, but it is possible that the progeny of infected females may become exposed to the parasite through contaminated ovarian fluid. In 2 other microsporidians of fish, Pleistophora (Plistophora) mirandellae and $P$. ovariae, spores were found within mature ova of the hosts (Vaney \& Conte 1901, Summerfelt \& Warner 1970, respectively), but there was no direct evidence of transovarian infection because the infected eggs were fragile and ruptured easily (Summerfelt \& Warner 1970). Nevertheless, these infected eggs appeared to release spores that subsequently attached to previously uninfected eggs, and atresia of infected ova may also release numerous spores into the ovary (Summerfelt \& Warner 1970). Progeny of control and infected female chinook salmon are currently being reared in $L$. salmonae-free well water to determine if the latter group will develop infections. If such is the case, routine screening of broodstock females with the PCR assay described in this study may control the spread of $L$. salmonae to subsequent generations.

Acknowledgements. We thank S. Dawe and Dr L. Margolis for review of the manuscript

\section{LITERATURE CITED}

Awakura T, Tanaka M. Yoshimiz M (1982) Studies of masu salmon, Oncorhynchus masou-IV Loma sp. (Protozoa; Microsporea) found in the gills. Sci Rep Hokkaido Fish Hatch 37:49-55

Barlough JE, McDowell TS, Milani A, Bigornia L, Slemenda SB, Pieniazek NJ, Hedrick RP (1995) Nested polymerase chain reaction for detection of Enterocyiozoon salmonis genomic DNA in chinook salmon Oncorhynchus tshawytscha. Dis Aquat Org 23:17-23

Bekhti M. Bouix G (1985) Loma salmonae (Putz, Hoffman et Dunbar, 1965) et Loma diplodae n. sp., microsporidies parasites de branchies de poissons téléostéens; implantation et données ultrastructurales. Protistologica 21:47-59

Docker MF, Kent ML, Hervio DML, Weiss LM, Cali A, Devlin RH (1997) Ribosomal DNA sequence of Nucleospora salmonis Hedrick, Groff and Baxa, 1991 (Microsporea: Enterocytozooidae): implications for phylogeny and nomenclature. J Eukaryot Microbiol 44:55-60

Hauck AK (1984) A mortality and associated tissue reactions of chinook salmon, Oncorhynchus tshawytscha (Walbaum), caused by the microsporidian Loma sp. J Fish Dis $7: 217-229$ 
Humason GL (1979) Animal tissue techniques, 4th edn. WH Freeman, San Francisco

Kent ML (1992) Diseases of seawater netpen-reared salmonid fishes in the Pacific Northwest. Can Spec Publ Fish Aquat Sci 116, Ottawa

Kent ML, Dawe SC (1994) Efficacy of Fumagillin DCH against experimentally induced Loma salmonae (Microsporea) infections in chinook salmon Oncorhynchus tshawytscha. Dis Aquat Org 20:231-233

Kent ML, Dawe SC, Speare DJ (1995) Transmission of Loma salmonae (Microsporea) to chinook salmon in sea water. Can Vet J 36:98-101

Kent ML, Elliot DG, Groff JM, Hedrick RP (1989) Loma salmonae (Protozoa: Microspora) infections in seawater reared coho salmon Oncorhynchus kisutch. Aquaculture 80:211-222

Magor BG (1987) First report of Loma sp. (Microsporida) in juvenile coho salmon (Oncorhynchus kisutch) from Vancouver Island, British Columbia. Can J Zool 65:751-752

Markey PT, Blazer VS, Ewing MS, Kocan KM (1994) Loma sp. in salmonids from the Eastern United States: associated lesions in rainbow trout. J Aquat Anim Health 6:318-328

Morrison CM, Sprague V (1981a) Electron microscopical study of a new genus and new species of microsporida in the gills of Atlantic cod Gadus morhua L. J Fish Dis 4:15-32

Morrison CM, Sprague V (1981b) Light and electron microscope study of microspondia in the gill of haddock, Melanogrammus aeglefinus (L.) J Fish Dis 4:179-184

Morrison CM, Sprague V (1981C) Microsporidian parasites in the gills of salmonid fishes. J Fish Dis 4:371-386

Morrison CM, Sprague V (1983) Loma salmonae (Putz, Hoffman and Dunbar, 1965) in the rainbow trout, Salmo gairdneri Richardson, and L. fontinalis sp. nov. (Microsporida) in the brook trout, Salvelinus fontinalis (Mitchill). J Fish Dis 6:345-353

Poynton SL (1986) Distribution of the flagellate Hexamita salmonis Moore, 1922 and the microsporidian Loma salmonae Putz, Hoffman and Dunbar, 1965 in brown trout, Salmo trutta L., and rainbow trout, Salmo gairdneri Richardson, in the River Itchen (U.K.) and three of its fish farms. J Fish Biol 29:417-429

Putz RE, Hoffman GL, Dunbar CE (1965) Two new species of Plistophora (Microsporidea) from North American fish

Responsible Subject Editor: L. Vaughan, Dublin, Ireland with a synopsis of Microsporidea of freshwater and euryhaline fishes. J Protozool 12:228-236

Qian L, Wilkinson M (1991) DNA fragment purification removal of agarose 10 minutes after electrophoresis BioTechniques 10:736-738

Sambrook J, Fritsch EF, Maniatis T (1989) Molecular cloning: a laboratory manual. Cold Spring Harbor Laboratory Press. New York

Shaw RW, Kent ML, Docker MF, Devlin RH, Adamson ML (1997) A new Loma species (Microsporea) in shiner perch (Cymatogaster aggregata). J Parasitol (in press)

Speare DJ, Brackett J, Ferguson HW (1989) Sequential pathology of the gills of coho salmon with a combined diatom and microsporidian gill infection. Can Vet $\mathrm{J} 30$ : $571-575$

Summerfelt RC, Warner MC (1970) Incidence and intensity of infection of Plistophora ovariae, a microsporidian parasite of golden shiner, Notemigonus crysoleucas. In: Snieszko SF (ed) A symposium on diseases of fishes and shellfishes, Spec Publ No 5. American Fisheries Society, Washington, p $142-160$

Vaney C, Conte A (1901) Sur une nouvelle microsporidie, Pleistophora mirandellae, parasite de l'ovaire d'Alburnus mirandella Blanch. C R Acad Sci 133:644-646

Vossbrinck CR, Baker MD, Didier E, Debrunner-Vossbrinck BA, Shadduck JA (1993) Ribosomal DNA sequences of Encephalitozoon hellem and Encephalitozoon cuniculi: species identification and phylogenetic construction. J Eukaryot Microbiol 40:354-362

Vossbrinck $C R$, Maddox JV, Friedman D, DebrunnerVossbrinck BA, Woese CR (1987) Ribosomal RNA. sequence suggests microsporidia are extremely ancient eukaryotes. Nature 326:411-414

Wales $\mathrm{JH}_{\text {, Wolf }} \mathrm{H}$ (1955) Three protozoan diseases of trout in California. Calif Fish Game 41:183-187

Wood JW (1974) Diseases of Pacific salmon, their prevention and treatment. State of Washington Department of Fisheries, Olympia

Zhu X, Wittner M, Tanowitz HB, Cali A, Weiss LM (1994) Ribosomal RNA sequences of Enterocytozoon bieneusi, Septata intestinalis and Ameson michaelis: phylogenetic construction and structural correspondence. J Eukaryot Microbiol 41:204-209

Manuscript first received: March 12, 1996

Revised version accepted: November 12, 1996 